\title{
COPING WITH THE VIRTUAL CAMPUS SOME HINTS AND OPPORTUNITIES FOR LEGAL EDUCATION?
}

\author{
JOHN GOLDRING*
}

\section{CHANGES ON CAMPUS}

The face of tertiary education may change rapidly over the next decade. The student of the future may "telecommute" to a "virtual campus". This prediction is probably an overstatement, but new technologies already have a significant effect on opportunities for people to learn.

In Australia, the present Commonwealth government is resolutely pursuing policies which ensure that the public tertiary education dollar is concentrated on providing as many places as possible to relatively affluent school leavers and members of "equity-targeted groups. High demand for places in LLB courses means that many students with good, but not outstanding, school results are discouraged from applying to study law. Others simply are not attracted to studying law until late in life. Opportunities for part-time oncampus study seem to be declining. The demand for places shows a considerable unmet need.

"Open learning" and "distance education" are seen by some as the answer. Even without the sci-fi fantasies of the "virtual campus", access and equity considerations may mean that open or distance learning courses may provide the only opportunity for many Australian students to study law in the near future. Fees may be introduced for all second degrees, so graduates who wish to study law will have to find a mode of study which will allow them to stay in paid work.

Some advocates of the educational applications of new technologies may not have considered adequately whether technology can achieve relevant learning objectives. A central question is whether open or distance learning (or other non- traditional learning modes that might be associated with a "virtual campus") deliver the same or similar learning outcomes at the same level of quality as full-time, oncampus, traditional legal education? Distance education courses leading to degrees in law, fully recognised both by professional accrediting authorities and by other Universities in terms of admission to postgraduate studies as being equivalent to at least three years' full-time University-level education, have been offered by the University of Queensland, Macquarie University, and Queensland University of Technology for decades.' In these Universities, the assessment tasks set for on- and off-campus students are very similar, if not identical, and the standards the same, though the learning experiences of the students might differ.

Different modes of legal education - including those associated with the "virtual campus" - are possible.

Increasing demand for places in LLB courses and "legal studies" subjects suggests that the question of whether there should be more distance education in law must be faced again. There may be questions about the employability of graduates of such courses, but here the question about the quality of learning in such modes is central. If faced squarely, it will lead as well to questions about traditional modes of legal education.

Take the example of the education of potential legal practitioners, (which is certainly not the only aim of legal education). Practising lawyers do not need to know how to memorise rules or pass exams. They need to know how to learn to find, understand and apply changing rules and practices, how to develop rational and telling criticisms of outmoded laws, how to conduct research independently, how to analyse fact situations, present arguments, and communicate and how to think creatively and laterally. Once these desired outcomes are articulated, some questions may be asked about the appropriateness of traditional 
styles and techniques of teaching and learning to achieving them. If the traditional techniques and approaches are not yielding the desired outcomes as well as might be hoped, it is necessary to ask what changes might result from new approaches and techniques.

\section{Adult Education, Distance Education and Open Learning}

In the broadest sense, "distance education" covers any course of studies where the student does not attend formal institutional sessions on a regular (daily, weekly, or fortnightly) basis. The student is required to learn independently, though some guidance and structure is supplied by the distance learning provider. ${ }^{2}$ The type of guidance varies: in some cases it consists of little more than a syllabus: in other cases it may be augmented by reading lists, detailed study guides, sets of problems, audio and video tapes, radio and TV broadcasts, teleconferencing, electronic mail and interactive computer systems. ${ }^{3}$

In some cases the provider merely establishes a syllabus, and arranges for formal examinations to be set and marked. At the other extreme, distance providers may set, assess and comment on regular written exercises; be available for telephone enquires, and organise regular formal class meetings. ${ }^{4}$ For reasons that will become apparent, different styles of distance education may be required if education in law is to be offered, whether as academic study, preparation for professional training, postgraduate study, practical training or continuing education.

Distance education is not the same as open learning. Open learning, ${ }^{5}$ while it may refer to openness of access, lack of restrictions on learning mode and rate of progress, and other requirements characteristic of institutional learning, certainly presupposes an absence of academic prerequisites. It is the smorgasbord of educational opportunity. Students, in theory, can help themselves to as much as they like of what is available whenever they like, regardless of their capacity to digest. Open learning could probably even be called a "take-away" smorgasbord, because in its pure form it does not require any formal contact. However, successful open learning programs in Australia, the UK, Canada, and elsewhere have found some system of contact with teaching staff is essential for effective and deep learning of high quality ${ }^{6}$

Adult education (andragogy ${ }^{7}$ ) has been conceived of differently from the education of children (pedagogy). Brookfield ${ }^{8}$ has listed some of the differences, including the fact that the program of studies acknowledges that the learners have prior knowledge and experience (something seldom recognised in traditional courses), the participation of adults is voluntary, and that there is an element of mutual respect among students in a group as well as mutual respect between teachers and students. These elements ideally should be present in primary and secondary schools, but often are not. University level education in Australia seems traditionally to have emphasised the pedagogical rather than androgological expects of learning, though in fact the students are adults — often not so young. Law schools, as will be seen later, in the author's experience, have been particularly prone to treat students as children rather than adults.

The academic legal education that is offered in Australia as a basic introduction to legal studies as part of a generalist degree could form part of an open learning array of courses, but almost all other academic courses in law assume and require some prior knowledge of the legal system. ${ }^{9}$ Within different law programs, it would not be practically possible for students to start anywhere. Law students need an introduction to the nature of legal rules, practices and institutions, and to legal reasoning, processes and materials before they dig too deeply into any substantive area.

Distance education, therefore, can be distinguished from "open learning” and from "adult education", though it may be a means of both.

It would be wrong to think of all modern distance education as merely a "correspondence course". Rather it is a significant (and, in some cases, cost-effective) opportunity to enter on a course of studies for students who otherwise would never otherwise have access to those studies. Though the learning environment may not be ideal, effective distance learning will give students many chances to encounter and grapple with a wide range of ideas, many opportunities for creative thought, intellectual development and research, and guidance and encouragement from experienced and accomplished academic staff.

After looking at some cases where distance education may have an important role, the basic issue of whether distance education can provide quality learning will be addressed. This will require a comparison with and assessment of traditional modes of teaching and learning law. 


\section{SOME OPPORTUNITIES FOR DISTANCE EDUCATION}

There seem to be strong demands for education in law that existing educational institutions cannot meet, sometimes because of the characteristics of the student group, sometimes because of geography, sometimes because of lack of resources. ${ }^{10}$ Tertiary awards acquired through distance learning in Australia are recognised for virtually every purpose as being equivalent to awards gained through internal study; the assessment tasks are equivalent, and where competency-based testing is required, all students must satisfy identical criteria. While the quality of the learning experience may vary, there may be an equal variation in the learning experiences of on-campus students.

Disadvantaged groups. In many countries today education is available only to those with money or with outstanding academic records that enable them to win scholarships. Children of lower-income households tend to perform worse in secondary school, or leave before completing it. ${ }^{11}$ Yet after a few years of employment, many such students develop the desire to study law, and qualify themselves educationally to do so. However, they cannot afford to support themselves (and often their dependents) for the three or four years of full-time study required. Courses that allow them to study without having to give up jobs or homes is a significant way of reducing the equity gap. Indeed this was the main reason for the establishment both of the Open University in the UK by the Wilson government in the 1960s and of the first distance education University courses in Australia. ${ }^{12}$

Isolated students. In both Canada and Australia, and more recently in the South Pacific, Sri Lanka, India and other countries, governments have established distance learning programs to provide opportunities for the geographically isolated. ${ }^{13}$ The most obvious groups are school teachers and public servants in rural or isolated areas (the mainstay of distance education in Australia). Postgraduate and continuing professional education. ${ }^{14}$ Possibly the greatest demand for courses of study in law by distance education will come from those engaged in full-time work, in cities as well as in isolated and rural areas, who are subject to heavy work pressures. They may be unable, because of work or domestic commitments, or a combination, to attend formal classes, and welcome the relatively self-paced style of distance learning. These students are often accomplished learners, with significant practical experience, seeking further study either to broaden their knowledge or to obtain a specialist qualification. For these students, by definition mature and responsible, a system of learning which is more susceptible of being tackled in discrete modules, and where they take full responsibility for the way they approach learning may be most appropriate.

\section{Technology and Distance Learning}

New technology, including educational television ${ }^{15}$ and interactive computer links, is now used quite widely in distance education. ${ }^{16}$ There is potential for much greater use of technology. Much new technology is expensive to develop and use, at least in the initial stages, and may not be as cost effective as traditional educational methods which are equally educationally effective.

In the UK, the government has poured millions of pounds into the development of computer-assisted instructional packages in a number of disciplines, including law. The Law consortium, which comprises staff of over 20 law schools, has already spent two years developing a set of contract law "courseware" as a prototype. There are difficulties, both technological and in achieving a common approach. While the project is exciting, the fact that the UK government has introduced financial incentives which amount almost to compulsion has encouraged some of the academics to make the necessary compromises. ${ }^{17}$ Some academics would see such compromises as incompatible with their professional judgment, and would not make them simply to en- sure that the program or course of studies they offer was compatible with those of others teaching in the same area. They may in future, have little choice,. They perceive threats to individual academic autonomy and fear that transnational media giants will monopolise the "Information Superhighway" - including educational materials.

It has been suggested that, in Australia, the Open Learning and PAGE initiatives, which have involved several Universities in delivering courses based on television broadcasts, but supplemented with print and other media, may produce a technology-led revolution in the approach of Australian academic 
administrators (if not academics themselves) to new modes of teaching. There are advantages in increased use of new technology, but the advantages may not be as great as some claim, nor may the changes be as rapid as some commentators suggest.

The Information Superhighway will undoubtedly provide access to a wealth of information. It may give students access to some self-paced courses. Television already has replaced (or supplements) the face-toface lecture in some larger universities and it may attract some students who might otherwise not study. Interactive computer-assisted instruction may become more accessible. However, if learning objectives include attainment of the higher stages in the cognitive domain this type of technology cannot yet be said to be appropriate, ${ }^{18}$ but it is very well suited to high-volume learning where lower levels in the cognitive domain are sought. It cannot yet handle complex multi-faceted problems at a cost that is realistic for universities.

Australians already have access to much information in public libraries, admittedly not while sitting in their home or office, even if the process of information retrieval be slow. One may ask whether many ordinary people will use more than a fraction of the information resources available - any more than they do now.

Complex, computer-based teaching technology is generally cost-effective in Australian tertiary education only where there are large classes in subjects that lend themselves to a fairly superficial approach. Some classes in some law courses may be of this type. In other cases, the introduction of technology usually occurs because teachers see it as a new, fascinating toy. They are challenged by what it requires, in instructional design, programming and other aspects of technology which lead the teachers along side tracks.

Cost is important. The model of distance learning developed at the University of New England involves close contact between on-campus staff and students and compulsory on-campus intensive sessions. Distance education at the Open University in England, by contrast, emphasises large student numbers, pre-packaged, intensively designed learning materials, and tutorial groups close to the students, rather than on a central campus. Holmberg considers that the model of distance learning developed at the University of New England is less cost-effective than the model developed by the Open University in England and the latter may therefore be preferable. ${ }^{19}$ Similar arguments, relating to the scale of operations, can and should be made about the use of technology. At times technology can and will improve legal education, but at present, cost factors alone, without any thought to some of the educational problems, suggests that available resources can probably be used more effectively in ways other than for heavy investment in new technology. Technology is an aid to or instrument of education. It is not education itself. Law teachers should not be mesmerised by it.

\section{TRADITION AND CHANGE IN LAW TEACHING}

Some law teachers and lawyers argue that, given the complexity of modern society, law can only be taught and learned in an intensive, full-time, on-campus academic environment, because what must be learnt includes competencies in listening, oral presentation, advocacy, negotiation and rational argument. History — and a considerable body of educational theory that examines how and why students learn indicates that other modes of learning may achieve the same or similar outcomes. Until the modern era the last 20 or 30 years - in Australia law was generally studied part-time, in isolation, and as an adjunct to apprenticeship. ${ }^{20}$ This traditional mode, though in some ways far from an ideal learning environment, may have had some advantages, such as the opportunity to observe law in action, and relate that observation and experience to law in the books. ${ }^{21}$

Universities, and law schools within them, have been singularly slow in applying new knowledge and technologies about how and why students learn to support and initiate improvement in teaching and learning. Although there have been experiments in legal education, the teaching of law, like most other university disciplines, appears wedded to the traditional lecture-and-tutorial or Socratic models. There have been many challenges to these models, but even if law teachers did not tend to be rather conservative, the restrictions flowing from the capture of education policy by economic rationalist ideologues ${ }^{22}$ in countries where higher education is a public or state responsibility is a major factor inhibiting introduction of new 
forms and modes of teaching and learning. Large classes and formal examinations appear cost-effective in times when education is starved of resources. Education bureaucrats and their political bosses demand educational outcomes measured in terms of numbers of graduates produced in the shortest possible time at the lowest marginal cost. ${ }^{23}$ The effect has been that pressures have been placed on law schools (and legal studies departments) to concentrate on mass instruction, regardless of quality. Even highly effective smallgroup methods ${ }^{24}$ developed and proved over the last 20 years virtually have been abandoned at the institutions which developed them. ${ }^{25}$ Today law teachers are probably clearer about the outcomes they seek from legal education but have not really thought through the methods of, and approaches to teaching and learning they use, in order to see whether they are the best way of achieving the desired outcomes. ${ }^{26}$

There are other reasons for considering change. Teaching institutions throughout the world are facing a crisis of resources, and must find new ways of producing the same, or better, learning outcomes with fewer resources. They must ask whether they are using their existing resources effectively. This should lead to a critical examination of existing techniques and an openness to experimenting with new methods.

Few would doubt that existing methods of teaching law can and should be changed to make them more interesting, more fun for teachers and students, more effective and more efficient Distance learning offers a number of attractions that may be cost-effective without diluting quality.

\section{Outcomes of Learning Law}

Institutions which teach law have a variety of objectives..$^{27}$ These range from introductory service courses (eg "law for surveyors") through sequences of subjects forming a major segment of a degree course (eg the law subjects required by the accounting professional accreditation bodies), the LLB course which is the academic foundation for a career in legal work, to specialist postgraduate courses. The range of objectives and intended learning outcomes will vary widely with the characteristics, capacity and motivation of the students.

\section{Students and Their Needs}

We know something about the background of LLB students in Australian law schools, ${ }^{28}$ but very little about the other university students who complete some studies in law. ${ }^{29}$ Nor do we know much about postgraduate law students, of whom there is a growing number. We know very little specifically about the way law students learn, about their approaches to and patterns of learning, ${ }^{30}$ or indeed, about other aspects of their professional socialisation. ${ }^{31}$ Nor do we know how these compare among LLB students, or as between LLB students and other students. We do not even know the numbers of students enrolled in law subjects (as opposed to say, law and commerce degrees).

Educational research has focussed on the way primary and secondary rather than tertiary, students learn and some of this material is available to tertiary teachers. ${ }^{32}$ How useful it is for tertiary teachers of law is not clear, because there is also evidence that as students become more mature, there may be changes in the way they learn..$^{33}$ However, if we knew more about this, it would be easier to think of, and test, alternative ways of teaching and learning law.

This absence of information does not mean that the task of teaching law is impossible, or even necessarily more difficult. However, it means that, at present, each law teacher must make a judgment about how to achieve learning objectives for each particular subject without an adequate background of general information about the way in which students - let alone specific groups of students with different motivations - approach learning law, or even how legal materials present different challenges to the way students learn. This general lack of background understanding means also that any method of teaching and learning relatively unknown to most law teachers produces a challenge, and feelings of wariness.

All students of law seek some knowledge, and probably some skills and attributes, but their motivation varies. There is no agreement on the knowledge that might be said to constitute a "common core" of studies in law (at any level), or even on whether there is such a common core. ${ }^{34}$ Even if a common body of knowledge can be identified as the object of study the level of abstraction or generality, and the detail in which students need to understand it will vary considerably depending on the desired learning outcomes. 


\section{The Liberal or Interdisciplinary Dimension}

Some law teachers, in "service" teaching as well as LLB courses, emphasise only the learning of rules, but most now agree that law can and should be studied not only as something practical but also as a means of developing a broader understanding of how society functions. ${ }^{35}$ These two facets are not polar, and most law studies in Australia today combine an element of the practical with an element of more general education. ${ }^{36}$ The mix depends on the learning objectives. However, the need to combine the two is something most law teachers have perceived or accepted relatively recently, and they find a change in method, as well, rather difficult.

There are both theoretical and practical reasons for a liberal or interdisciplinary dimension in law teaching. Like many people working in business, commerce, and some professions, enlightened academics realise the artificiality of discipline boundaries and work in interdisciplinary teams. Research in such diverse matters as environmental studies, medical ethics, ownership and control of the media, and fisheries reform all require an understanding of relevant legal factors. Academic lawyers increasingly realise that by working with scholars from other disciplines, they gain insights into the workings of the legal system. This has led to the development of legal subjects which enhance courses in, for example, the humanities, social sciences, and commerce.

If the capacity for independent, critical thought (ie a "liberal education") is a desired outcome of legal education, we must ask whether existing approaches to and methods of teaching and learning law are the best way to deliver this, or whether other approaches, including distance learning, may do as well.

\section{The Professional Dimension}

In Australia and other common law countries legal education traditionally has been, if it is not still, dominated by the practising legal profession. Law schools were set up to provide recruits for an expanding legal profession, not to conduct scholarly research into law. ${ }^{37}$ Scholarly activity was a by-product. Teaching and learning law eventually took place in university law faculties, but the teachers were overwhelmingly practitioners who taught on a part-time basis. Despite this, there was little attention to the "practical" element of professional training, because that was accomplished primarily by a system of apprenticeship. Indeed, most practising lawyers thought of the apprenticeship as the primary focus of training, with the "academic" side - confined mostly to formal lectures and formal examinations — as a rather irksome adjunct. The traditional law schools tended to foster this attitude, though over the years all have changed their emphasis from part-time to full-time staff and students. During this period, most law students were obliged to develop their own learning techniques, and to learn independently

The first formal University courses in common law were essentially superficial guides to the legal rules, delivered in formal style and tested exclusively by terminal examinations. This pattern was followed in Canada and Australia, and was the prevailing ethos in some of the older and larger Australian university law schools. ${ }^{38}$ Vestiges survive at a few Australian law schools. ${ }^{39}$ In this type of learning, students are not encouraged to think about the social content of the law, or to develop flexible learning techniques. They are encouraged to see the law as a "given", to be learned by rote and regurgitated in examinations.

The training of those who wish to become legal professionals and paraprofessionals ${ }^{40}$ requires a mix of two aspects of understanding law: "learning [to do] law" - that is, learning how to find and apply appropriate legal rules to specific factual situations in order to resolve conflicts or guide social behaviour; and "learning about law" which is, in essence an exercise in hermeneutics - interpreting the social function of legal rules, practices and institutions, or, put another way learning how to "demystify" the law. The two complement each other, and cannot be separated if the student is really to understand law, which is both a system of rules and a vital force in the operation of our society.

\section{CAPACITY FOR INDEPENDENT LEARNING}

Whatever their learning objectives, the most important outcome any student can gain from legal education is the capacity to learn for him- or herself, or, in other words, the capacity to understand and adapt to change. ${ }^{41}$ The law — rules, practices, institutions — changes constantly and in the future is likely 
to change even more rapidly To study law is to study change; to learn law is to learn how to cope with change; and to build a conceptual framework which accommodate change. Such study requires a "map" of the legal system, an understanding of legal language and legal reasoning, and a familiarity with legal culture, which can be gained only through development of capacity to synthesise and evaluate particular areas of law. The scale and scope of the map will vary. A law degree course should cover the legal system as a whole, with some detailed knowledge of how it affects certain areas of human activity. It needs to be directed to producing what is known as a "deep" approach to learning, described later. By comparison, a short course on law for, say marketing managers will cover a vastly smaller range of law, and will probably focus on relatively few rules in some detail. Such a course may be directed at a much shallower or more superficial approach to learning, because the learning needs of lawyers about legal rules, practices and institutions are vastly different from those of marketing managers.

Understanding the process of law, either broadly within society, or as it affects a particular area of work or other social activity, is as important for lawyers as understanding the specific rules governing some particular type of human interaction. Learning the processes will almost certainly involve a detailed study of one or more concrete areas of law. It would be impossible for any student to cover every area. This is true whether or not the objective is to prepare a student for a career in law or to provide a general or critical education through the study of law.

A practitioner who works extensively in any area of legal work will gain detailed knowledge or familiarity with relevant statutes and cases, and the way they are applied in routine situations, but the real test of the quality of the practitioner's learning process is his or her ability to deal creatively, imaginatively and competently with the client's problems as they arise, relying increasingly on the sophisticated devices that are now available for the retrieval of detailed legal information.

The study of law requires, in addition to detailed knowledge of the rules and how to find them, additional skills: how to elicit information from the client and others, how to present information in the manner required, how to use technology to improve the quality and effectiveness of service delivery, how to draft effective documents, and so on. These skills can be taught and learnt, ${ }^{42}$ and there is significant evidence that institutions do this better, or at least more consistently, than untrained individual practitioners as principals.

\section{DEEP APPROACHES TO LEARNING}

A legal "education" which consists of the rote-learning of bodies of rules (which some people think makes up "the law") is probably not a desired learning objective, and may be positively inimical to equipping a student intellectually for a career in law — or anything else. Marton and Säljö ${ }^{43}$ identified a distinction between "surface” and “deep” approaches to learning, and this might usefully influence the ways in which legal education is planned and offered. Students taking a surface approach tend to learn by rote, not to question the assumptions that underpin the material nor to relate it to context. Students with a deep approach examine the arguments critically, question the assumptions on which they are based and relate them to previous knowledge and understanding. Ramsden, ${ }^{44}$ among others, indicates that University level education should foster a "deep” approach to learning: the development of understanding which is not superficial or easily forgotten. Understanding of legal material, both from a perspective of internal consistency and structure, and of its relations to the social context, is essential to the making of sound professional judgments and evaluations. Much traditional legal education was little more than training to pass final examinations. Much of what was learned was forgotten, let alone understood. Students did not participate in the learning process. They were encouraged to take a superficial approach to learning because their learning objective was to pass examinations, rather than to understand the subject matter, and traditional law school exams tested only a limited level of understanding. It was possible to satisfy the examiners by regurgitating lecture notes, or applying reasoning skills to the problems presented. If law students developed a deep approach to learning, it was in spite of, rather than because of their education.

If capacity to learn and the development of deep approaches to learning are desired outcomes of the educational process, whether existing methods deliver the outcome must be tested, and compared with alternatives, including distance education. 
Any law course at tertiary level, then, will have learning objectives related to knowledge of specific rules, practices and institutions; to skills of locating, interpreting and applying rules, of ascertaining and of determining the relevance of facts (analysis and synthesis); and of evaluation at a number of levels: from choosing an appropriate rule or principle, to assessing the social worth of particular rules and of the policies which they embody.

The methods used to teach should depend on the particular learning objectives selected for the particular course or subject.

\section{ARE TRADITIONAL METHODS APPROPRIATE?}

Some learning outcomes that law courses should produce have been mentioned. They include the development of certain skills and approaches. This section will examine whether the techniques of teaching and learning employed traditionally in law school are likely to lead to those outcomes, and whether other techniques - including those used in distance education, might not do so as well or better.

The lecture developed in the middle ages. ${ }^{45}$ When academics are forced to deal with class numbers that make small-group methods impossible, their tendency (if not their inclination) is to retreat to the only other style of teaching with which they are familiar - the traditional lecture. In some other disciplines the dominance of the lecture has never been questioned. Most Australians, including many academics, simply assume that the major part of university teaching will be in the form of lectures. There are good reasons for questioning, indeed, for overthrowing this assumption.

A lecture to 500 students is an effective way of communicating information - but print or electronic media may be even more effective. Before the printing press, face-to-face teaching was probably the most effective way of communicating information to a wide audience. Rote-learning was required if the information was not to be lost. We should be thankful for this oral tradition which has produced the epics and legends which are major foundations of many cultures, not least the Western Judaeo-Christian culture, of which the common law legal culture is part. But there are now better methods of communication - at least with a cohort of learners whose upbringing tends to give them short attention spans. These methods allow the learners to devote their mental energy to thinking - to analysing, comparing, synthesising and evaluating - rather than simply to committing strings of words and phrases to memory. There are indications that other techniques, which build on students' experiences and involve them actively in learning, produce more of the desired outcomes more effectively.

Most university teachers simply have not thought of those different ways, or if they have, find that university structures, modes of thought or finances will not allow them the resources to produce suitable instructional media. The newer Australian law schools (those established in the 1970s) attempted to abandon or reduce the emphasis on lectures, and increase the use of problem-solving or Socratic seminars. They did so largely without the benefit of a full understanding of theories of teaching and learning, but because of an appreciation that other techniques could only improve on the traditional methods.

As university education moves from an elitist privilege to a claim for universal access, there will be growing pressure to do more with less, and therefore increasing pressure to abandon staff-intensive modes of instruction. The decline in resources available in the 1990s has produced pressure on these schools to abandon innovative non-lecture methods. Many have chosen retreat to the traditional large-group lecture. This may be a false economy The real cost is likely to be a significant decline in the quality of learning.

\section{Do We Need Face-to-Face Teaching?}

Can learners learn on their own? Without doubt, some people grasp and retain information, and possibly develop the ability to apply or evaluate it, on their own. Others find that they learn best when they are talking with peers or participating in problem solving — for example, by seeking to apply what they have learnt. Others actually do learn best simply by listening and reflecting, though there are probably relatively few of these. But at some stage, all learners must be able to communicate what they have learnt. This will involve them in some form of interaction with other humans. ${ }^{46}$ How much will depend on a variety of factors. If financial or other factors preclude some of the intense, small-group learning modes, teachers need not return to the lecture, and its relatively limited value. There are alternatives which, in the long run, may 
allow students to learn more effectively and at lower cost. If law teaching is to be effective, law teachers must learn to cope with the pressure to do more with less, and do it better. This is not to suggest, as some cost-conscious observers of distance education have suggested ${ }^{47}$ that face-to-face contact with students should be eliminated. The evidence produced in Cameron's study indicates that distance students value highly contact with teachers and with other students in the course. ${ }^{48}$

\section{Developments in Teaching and Learning Law}

Increased attention to how and why we teach law means that we should not only be able to use traditional methods more appropriately and effectively, but also develop and adopt new and different methods to provide more effective and efficient legal education.

In the past it has been easy for law teachers to assume that the learning objectives, say, of a subject in an LLB course or an accountancy course are set by some external body - such as a Court or professional accrediting body. Even within the limits allowed by such bodies, or the rather rigid curriculum requirements of most Australian universities, there is scope, and, indeed, a need, for each teacher or teaching team to reexamine the teaching and learning objectives of each subject or unit regularly, considering the academic, vocational, and, where possible, the individual or group needs of the students. The demands for accountability and quality in education emphasise these requirements.

The more we know about the different learning needs and approaches of students overall, the more accurate our assumptions about specific groups are likely to be. It is fairly safe to assume that LLB students want to learn how to analyse facts, find legal principles and apply them to facts, if not also to be able to understand the role of law in society. Any of these desired outcomes requires a deeper approach to learning than the superficial memorisation of rules; it requires the ability to synthesise and evaluate. A student in Arts or Commerce might want a different sort of learning, possibly more practical, more descriptive, more superficial, or more theoretical, depending on the circumstances - but, on the other hand, the commerce student who wants to specialise in taxation may need much of the same knowledge and skill in taxation law as the LLB student. The postgraduate student wishing to specialise in say, environmental and planning law, will want not only a deep understanding of policy issues, but also a detailed knowledge of specific legal rules.

\section{Student-centred Learning}

Until recently, Universities have assumed that most learning is teacher-centred. Both adult educators ${ }^{49}$ and distance educators ${ }^{50}$ have accepted that the student, while possibly needing guidance, is central to the learning process. Most academics have simply not thought about what their students want or need to learn. As teachers, they are the authority, and their judgment alone determines what is taught - and how it is taught. This is not congruent with what is learnt.

Put simply student-centred learning refers to a learning environment in which the student has greater control over what is learnt and, particularly, how it is learnt. ${ }^{51}$ The student takes responsibility for learning. The learning is more likely to be deep. Student-centred methods can be applied just as easily where the object is a more superficial type of learning. The function of the teacher is to provide direction, resources, encouragement, and indicators of how effectively the student is learning. The teacher is simply not a tank of notions, pouring them forth into the classroom where droplets may be absorbed by students, who regurgitate them in examinations. This is what happens in most lecture-style teaching, though there are exceptions.

Student-centred learning does not necessarily refer to a situation where the student chooses dollops from the smorgasbord of knowledge: a better metaphor would be the student making a choice from a table d'hote carefully designed with sound nutritional principles in mind, but prepared with gourmet care. The student's choice is limited, but the consumer participates in the way in which needs are satisfied. The following material addresses some of the issues that flow from this degree of participation.

\section{Legal Education and Distance Education.}

University legal education - in the sense of a course of studies which provides the whole, or a significant part, of the academic prerequisites for a qualification to engage in legal practice in a common 
law country - is relatively recent. From its inception in the University of London in the 1830s, some students have not attended classes in the Colleges of the University, but have studied externally - in private institutions or at home. A relatively large number of students has read for the London LLB. ${ }^{52}$ In Australia, there is also a strong tradition of distance education, both generally and in law. ${ }^{53}$

The traditional mode of distance education was the "correspondence" model, which was adopted by the Universities of London and Queensland for their external LLB degrees. ${ }^{54}$ In this model the University's role was limited. It prescribed the syllabus for the degree, registered the students, sent them the syllabus (which usually included a reading list of cases and a few prescribed textbooks, but rarely any directions for wider reading), set and marked examinations, notified students of the results, and awarded the degree. The syllabus and examinations were common for all internal and external students, and held at the same time. So far as the University of London was concerned, it was cheap and effective, especially in a "federated" University whose central functions were limited to setting the syllabus and examining students, and most where teaching was a matter for the constituent colleges. ${ }^{55}$ Internal students were able to attend classes at one of the colleges. Tuition for external students could be, and often was, provided by other institutions. Private firms of law tutors in many parts of the world traditionally have coached students for the London LLB exams. In some parts of the Commonwealth where local institutions cannot satisfy the demand, local Universities and colleges have offered tuition for the London degrees. ${ }^{56}$ Students en- rolled in these courses need not, however, have been exposed to any formal teaching at all. Textbooks and student aids have been prepared for London LLB students, but learning was (and remains) solitary, largely superficial and generally directed to the sole object of satisfying the examiners, subject by subject. The experience may have provided some academic foundation in law, but could not really be described as a broad education.

By contrast, the School of Law at Macquarie university ${ }^{57}$ was established primarily to provide distance education in law to supplant the NSW Admission Board courses, and provide an academically respectable course of studies for people who could not attend university full-time, particularly court clerks, solicitors' clerks and police prosecutors stationed outside the Sydney metropolitan area. ${ }^{58}$ Each LLB subject at Macquarie was designed by staff with a view to the learning needs of external students. The Centre for Evening and External Studies at the university had considerable experience in developing distance education in science for the first time in Australia, and gave valuable guidance to the law staff in how to design and present material to facilitate independent learning by external students. The materials designed in this way were also used by internal students. Staff soon found that lectures to the internal students were largely superfluous. They and the students found it more worthwhile to spend class time discussing problems which required students to analyse and apply the materials which they had previously read. The students found this active participation in class developed not only their self-confidence in learning, but also their skills of listening and oral presentation. Macquarie's graduates are now in wide demand because they have developed the ability for independent work and further learning, and a sense of policy implications which other law graduates may not have developed to the same degree. Much of the approach to teaching and learning (though possibly not to content) developed at Macquarie has been adopted as the basis of the approach to teaching and learning at some newer law schools.

\section{CAN DISTANCE LEARNING DELIVER QUALITY?}

More recent exercises in distance teaching in law have moved away from the "London" model, and seem educationally superior. This conclusion is founded on an examination of the outcomes desired in legal education, and whether the learning experience of the students learning in particular modes is more or less successful in achieving those outcomes than the experience of students using more traditional modes.

It is extremely difficult to state categorically what is a "good lawyer". However, earlier in this paper some desired outcomes are listed. ${ }^{59}$ Experience suggests that a learning environment where the student is in control, and participates in the learning process, is more likely to achieve the outcomes than one where the learning process is more passive or receptive. Distance education, if properly planned and executed, may be able to achieve the desired outcomes. For example, a student using a version of problem-based learning might work as well in her own home as on campus. Structured readings, reinforced with audio tapes and questions (with feedback provided in appropriate ways) may result in a student having a better competence 
in many of the attributes which the process hopes to achieve. In Australia no study has compared the effectiveness of on- and off-campus modes of learning in law. Macquarie and QUT have statistics of the pass rates and grades of students studying the same subjects by different modes, but these cannot tell a great deal about the effectiveness of the method, as the selection criteria for the external course (at Macquarie at least) are significantly different from those of the on-campus course, so the students in the different modes have different levels of academic ability, educational, employment and socio-economic backgrounds at the beginning of the course, even though the assessment methods are identical or vary only slightly. Without such quantitative studies, the only evidence available is anecdotal. It suggests that distance learning can deliver at least similar levels of quality in learning as some on-campus modes of learning. A comparative study might be useful. However, even without such studies, the exigencies of contemporary tertiary education policies suggest that, even if only to achieve access and equity Universities should attempt to deliver some law courses by distance mode. If they make that choice, they should have little worry about educational standards or quality of learning.

\section{THE CHOICE}

The choice law teachers must make is not between the 18th century and the 23rd. The 20th-21st centuries have produced some developments of which law teachers could, but have not, availed themselves. The traditional lecture and tutorial methods can be used, but the educational outcomes may not be what is needed or desired. Other methods, including distance education, which may require a little more thought and preparation in the short term may deliver learning outcomes at all levels.

The conclusion which this article is intended to support is that use of different methods of creating learning environments may improve the quality of law teaching designed for a range of purposes. In itself, that is a reason for re-thinking existing methods. In addition, distance education specifically may provide access to legal education at a number of levels for those to whom such access is presently denied and may in fact be the only way in which a significant group of people may obtain access to knowledge about law and the means of entering the legal profession. The evidence is that it may provide education and a learning experience at least of the quality offered by many on-campus LLB courses.

* Professor of Law, University of Wollongong. From 1981 to 1987, as Professor of Law at Macquarie University, the author was actively involved in the management and improvement of distance education in law.

1 Some questions have been raised about the duration and educational quality of the old NSW Solicitors' and Barrister's Admission Board courses, which was available by correspondence to a limited number of students. The author was Chairman of a Subcommittee of the NSW Legal Qualifications Committee which conducted an academic review of these courses in 1993-4. The report of the Sub-Committee was not publicly available at the time of writing. The author's personal view is that these courses are not of the same quality or duration as the majority of University law degrees in Australia.

2 Compare: "[T] $]$ he various forms of study at all levels which are not under the continuous, immediate supervision of tutors present with their students in lecture rooms or on the same premises, but which, nevertheless, benefit from the planning, guidance and tuition of a tutorial organisation” per B Holmberg, Status and Trends of Distance Education, 2nd ed (Lund: Lector Publishing, 1985) at 1; and "[A] system based on the selective use of instructional media that promotes the self-teaching learning process to achieve specific educational objectives” per ML Ochoa, "Some basic issues on implementing a distance education system” in M Neil, ed Education of Adults at a Distance (London: Kogan Paul, 1981) 198, at 199.

3 Holmberg, supra note 2, ch. 4

$4 \quad$ Infra at $112-115$.

5 eg R St C Johnson, Open Learning, Canberra, AGPS 1990.

6 Holmberg, supra note 2; compare $\mathrm{J}$ Cameron et al, On campus activities in the nationwide provision o distance education (Canberra: AGPS, 1991), who differentiate between availability of teaching staff and on-campus activity, suggesting that the latter may not be necessary. However, their survey did not include any external LLB students.

7 See eg M Knowles, The Adult Learner: A Neglected Species (Houston: Gulf, 1984). The concept originally developed by Knowles is not new: see SE3 Merriam, ed, An Update on Adult Learning Theory (San Francisco: Jossey-Bass, 1993), and especially .the article by DD Pratt, “Andragogy after twenty-five years”.

8 eg Understanding and Facilitating Adult Learning (San Francisco: Jossey-Bass, 1987).

9 The literature on this subject is summarised well in DC Pearce, EM Campbell and DE Harding, Australian Law Schools: A discipline assessment for the Commonwealth Tertiary Education Commission (Canberra: AGPS, 1987) ("Pearce Report”).

10 eg M Neil, ed Education of Adults at a Distance (London: Kogan Paul, 1981): J Anwyl et al, Who uses external studies? Who should? (Melbourne: CSHE University of Melbourne, 1987); Cameron et al, supra note 6.

11 R Connell, Making the Difference (Sydney: George Allen \& Unwin, 1982). See also Holmberg, supra note 2, chs 1,2,7.

12 W Perry, Open University. A personal account by the first Vice-Chancellor (Milton Keynes, The Open University 1976); Anwyl et al, supra note 10.

13 NA Kuhanga 'The concept of adult education at a distance and its application in developing countries' in Neil, supra note 10.

14 Holmberg, supra note 2, ch 8.3. In the case of law, these possibilities are considered more fully in J Goldring \& H Eyre, Report On 
Distance Teaching And Learning Of Law In The Commonwealth, Commonwealth Legal Education Association, Commonwealth Lawyers' Association, The Commonwealth of Learning and The College of Law, England, Commonwealth Secretariat, London, 1993.

15 Satellite television is used extensively in distance education by the University of the South Pacific; slots on regular television are used by the Open University in the UK and now by the Open Learning and PAGE consortia in Australia.

16 eg R Caladine, Overseas experience in non-traditional modes of delivery in higher education using state-of-the-art technologies (Canberra: AGPS 1993).

17 Personal communication 1993-1995, Dr A Paliwala, School of Law, University of Warwick, who is the convenor of the TLTPLaw Working Party.

18 See B Bloom et al, Taxonomy of Educational Objectives (New York: McKay, 1956).

19 Holmberg supra note 2, ch 7.

20 L Martin, From Apprenticeship to Law School: A Social History of Legal Education in New South Wales (1986) 9 UNSWLJ 111; M Chesterman \& D Weisbrot, Legal Scholarship in Australia (1987) 50 Modern L Rev 709; J \& J Mackinolty, A Century Down Town (Sydney University Law School, 1991).

21 D Boud, Experience as the base for learning (1993) 12 Higher Educ Research and Dev, 33, argues that some extremely effective learning is achieved where students can relate the subject of learning to their one experience; cf DA Schön, Educating the Reflective Practitioner (San Francisco: Jossey-Bass, 1987); D Wildermeersch \& T Jansen, eds, Adult Education, experiential learning and social change: the postmodern challenge (s'Gravenhage: Vuga, 1992).

22 See S Marginson, Higher Education and Public Policy (Melbourne: Cambridge UP, 1993).

23 Marginson, id, discusses these policies in detail.

24 See Pearce Report, supra note 9, ch 3, paras 3.14-3.22.

25 Class sizes at the University of NSW Law Faculty, which was the pioneer in small-group teaching of law in Australia, were 15 in 1975, but now average 35-40.

26 This is the point of M Le Brun \& R Johnstone, The Quiet Revolution (Sydney: Law Book Co, 1994).

27 I have discussed a number of these in Better Legal Education — An Essential Element of Justice for All in Papers delivered at 28th Australian Legal Convention, Law Council Of Australia, Hobart, September 1993, Vol 1, at 23.

28 J Goldring, “Admissions Policy” in Law Foundation of N.S.W., Legal Education in Australia, Sydney, 1976 (Reprinted in Law Council of Australia Foundation, Legal Education in Australia, Melbourne, 1978); Admission of Students to Law Schools in Australia (1977) 20 Vestes 61; An Updated Profile of Students Entering Law Courses (1986) 29 Australian U Rev, 2, 38-45; A Ziegert, Social structure, Educational Attainment and Admission to Law School (1992) 3 Legal Educ Rev 155.

29 But see DW Mitchell, ed, Papers on Legal Studies and Legal Education for Non-Lawyers (Sydney: Butterworths, 1977).

30 The importance of this is well documented. See M Le Brun \& R Johnstone, supra note 26, chs 2, 6; see also (more generally) J Biggs, Students' Approaches to Learning and Studying (Hawthorn, Vic.: ACER. 1987); P Ramsden, Student Learning Research: Retrospect and Prospect (1985) 4 Higher Educ Research and Dev 1, 51. Le Brun, McCrimmon and Bond are currently conducting some studies into students' approaches to studying law in some Queensland Universities (Personal communication, 1994-5).

31 The only serious Australian study I know of is DS Anderson \& JS Western, What a law school does to you (1974) Oracle 74, 22 a brief and impressionistic account of a side-effect of his study in the early 1960s of students in four professions.

32 eg L Renstrom, B Andersson \& F Marton, Students’ conceptions of matter (1990) 82 J Ed Psych 555.

33 P Ramsden, Learning to Teach in Higher Education (London: Routledge, 1992) ch 5; cf G Gibbs Improving the Quality of Student Learning (Bristol: Technical and Educational Services Ltd, 1992) ch 16.

34 See FN Dutile, ed, Legal Education and Lawyer Competency, Notre Dame and London 1981; American Bar Association, Section on Le a1 Education and Admissions to the Bar, Legal Education and Professional Development - An Educational Continuum: Report of the Task Force on Law Schools and the Profession: Narrowing the Gap (Chicago: ABA, July 1992) ("The McCrate Report”); Lord Chancellor's Advisory Committee on Legal Education and Conduct, Review of Legal Education, Consultation Paper, London, 1994.

35 See Pearce Report supra note 9, and particularly Legal Education In Australia; Submission of the Australian Law Deans, reproduced in Vol 3.

36 In its "Legal Education Policy" adopted in 1993, the Law Council of Australia calls for a "course of study [that] must provide the intellectual foundation on which further knowledge and skills can be assembled. As part of the course of study leading to admission to practise, the student must obtain an understanding and knowledge of the following areas of law in the context of an overall course of study which provides:

a well-rounded education in the law;

a level of scholarship usually associated with a course leading to an undergraduate degree;

a good grounding in the analytical, communication and other skills required of a lawyer in modern society, and which places the theory in a practical context.

The course of study should also provide an understanding of the historical, philosophical and ethical and social context of the law.

37 eg L Martin, From Apprenticeship to Law School: A Social History of Legal Education in New South Wales (1986) 9 UNSWLJ 111; J Goldring, Babies and Bathwater: Tradition and Progress in Legal Education and Legal Scholarship (1987) 17 URAL Rev 216; Chesterman \& Weisbrot, supra note 20; D Weisbrot, Australian Lawyers (Melbourne: Longman Cheshire, 1990); J \& J Mackinolty, A Century Down Town (Sydney: University Law School, 1991). For a US perspective, see R Stevens, Law School (Chapel Hill: UNCLE Press, 1983).

38 The Pearce Report criticized this aspects of Australian legal education, especially the professional course in NSW, and in the Universities at least, the Pearce Report produced some changes: see C McInnis and S Marginson, Australian Law Schools after the 1987 Pearce Report (Canberra: AGPS, 1994).

39 And the professional examinations for the Admission Board Course in the State of NSW. Three Law Schools - at the University of NSW, Macquarie and University of Technology, Sydney (then the NSW Institute of Technology) — were established respectively in 1969, 1973 and 1977, at least in part expressly to take over the functions of the professional course, but vested interests have always ensured its retention. The universities always insisted on restricted entry to maintain standards, and demand always exceeded the number of places. The course is currently under review again. The Legal Qualifications Committee publishes a syllabus and conducts examinations in a number of subjects prescribed by the Rules. Until about 1970, there was no forma teaching, though now the Law Extension Committee of the University of Sydney conducts lectures and some external teaching programs. 
$40 \mathrm{~J}$ Goldring, Professions and Paraprofessionals, in J Vernon \& F Regan, eds, Improving Access to Justice (Canberra: Australian Institute of Criminology Conference Proceedings No 3, 1991).

41 Since this paper was written this view has been thoroughly endorsed by a Commissioned Report (No 29) for the National Board of Employment, Education and Training: P C Candy et al, Developing Lifelong Learners Through Undergraduate Education (Canberra: AGPS, 1994).

42 N Gold, K Mackie \& W Twining, Learning Lawyers’ Skills (London: Butterworths, 1989).

43 F Marton \& R Salvo, On qualitative differences in learning - 11. Outcomes as a function of the learner's conception of the risk (1976) 46 British J Educ Psych 115.

44 P Ramsden, Learning to Teach in Higher Education (London: Routledge, 1992). See also Le Brun \& Johnstone, supra note 26.

45 See DA Bligh, What's the Use of Lectures? (Harmondsworth: Penguin, 1972).

46 J Big S, Students’ Approaches to Learning and Studying (Hawthorn, Vic: ACER 1987); Ramsden, supra note 30.

47 Cameron et al, supra note 6 .

48 This is certainly the author's own experience with law students at Macquarie University. The contact provided strong reinforcement to students, enabled them to develop networks, and, in the context of a law degree, encouraged them to develop skills of communication, argument, advocacy and negotiation, as well as an awareness of some of the intellectual dimensions which they would not likely have gained on their own.

49 S Brookfield, Understanding and Facilitating Adult Learning (San Francisco: Jossey-Bass, 1987); Merriam, supra note 7.

50 Holmberg, supra note 2.

51 eg PC Candy, Self-Direction for Lifelong Learning (San Francisco: Jossey-Bass, 1991); G Piskurich, Self-Directed Learning (San Francisco: Jossey-Bass, 1993); Holmberg, supra note 2; Brookfield, supra note 49.

52 W Twining, 1836 and all that: Laws in the University of London 1836-1986, (1987) 40 Current Legal Problems 261. Even now, the external LLB from the University of London, even though entirely focussed on English law, is as eagerly sought in many Commonwealth countries as it is in England. It is and always has been, open to students anywhere who have satisfied the basic matriculation requirement of the University of London.

53 J Goldring, Distance Teaching in Law: Possibilities for Commonwealth Cooperation (1990) 2 Legal Educ Rev 83.

54 See Holmberg, supra note 2, ch 2 for a criticism of this model.

55 Twining, supra note 52.

56 The Department of Extra-mural Studies at the University of Hong Kong provides classes for a large numbers of Hong Kong residents enrolled in the external London LLB course. These classes are taught by staff which include academics from London flown out for the purpose, some staff of the Faculty of Law at the University of Hong Kong, and some other part-time staff. In Malaysia, a number of private educational institutions employ local law graduates as part-time lecturers and tutors for students enrolled in the London course. The Australian College of Law, a private institution, offers tuition for the London external LLB in Melbourne.

57 Detailed descriptions of distance teaching in law in Australia and elsewhere may be found in J Goldring, Distance Teaching in Law: Possibilities for Commonwealth Cooperation (1990) 2 Legal Educ Rev 83 and J Goldring \& H Eyre, Report On Distance Teaching And Learning Of Law In The Commonwealth, Commonwealth Legal Education Association, Commonwealth Lawyers' Association, The Commonwealth of Learning and The College of Law, England. Commonwealth Secretariat, London, 1993.

58 It was not the first external law course in Australia. See Goldring \& Eyre, id. While at Macquarie University I saw some correspondence between the Justice Department of NSW and the University which made this clear. The view was confirmed by the late AJT Ford, the founding Registrar of the University, and by the late Professor J Peden, my predecessor as Head of School, who had been part of the staff from the outset.

59 Supra at 103-108. 